\title{
Simulasi Penerapan End Plate Wing Tip Devices pada Pesawat Model Unmanned Aerial Vehicle Jenis Fixed Wing Glider
}

\author{
(Simulation of End Plate Wing Tip Devices on Fixed Wing Glider Unmanned Aerial Vehicle)
}

\author{
Azhim Asyratul Azmi ${ }^{\mathrm{a}}$, Wahyudi ${ }^{\mathrm{b}}$, Aris Widyo Nugroho ${ }^{\mathrm{c}}$ \\ ${ }^{a, b, c}$ Program Studi Teknik Mesin, Fakultas Teknik, Universitas Muhammadiyah Yogyakarta \\ Jalan Brawijaya, Tamantirto, Kasihan, Bantul, DI Yogyakarta, Indonesia, 55183 \\ e-mail: azhim.asyratul.azmi@gmail.com,wahyudi_stmt@yahoo.co.id, nugrohoaris@gmail.com
}

\section{Abstrak}

Aliran udara yang bergerak dari tekanan tinggi ke tekanan rendah menimbulkan pusaran udara pada ujung sayap atau biasa dikenal sebagai wing tip vortices. Wing tip vortices menyebabkan downwash yang mengurangi nilai gaya angkat pada sayap. Berbagai tipe wing tip devices kemudian dirancang untuk mengurangi wing tip vortices, salah satunya adalah wing tip devices jenis end plate. Penelitian pengaruh penerapan wing tip devices dengan variasi sudut kemiringan dapat menggunakan metode pendekatan simulasi. Wing tip devices jenis end plate dirancang dengan desain mengacu pada Withcomb winglet bagian atas. Objek simulasi meliputi pesawat model glider tanpa end plate, menggunakan end plate dengan sudut kemiringan $0^{\circ}$ dan end plate dengan sudut kemiringan $15^{\circ}$. Simulasi dilakukan dengan tiga variasi kecepatan jelajah 50, 60 , dan $70 \mathrm{~km} / \mathrm{jam}$. Hasil simulasi menunjukkan bahwa penerapan end plate dapat meningkatkan nilai gaya angkat. Persentase peningkatan terbesar yaitu 4,1\% menggunakan end plate dengan sudut kemiringan $15^{\circ}$ pada kecepatan 70 $\mathrm{km} / \mathrm{jam}$. Persentase penurunan nilai gaya hambat terbesar terjadi pada konfigurasi end plate dengan sudut kemiringan $15^{\circ}$ pada kecepatan $50 \mathrm{~km} / \mathrm{jam}$ yaitu sebesar $1,04 \%$. Hasil kontur dan iso surface menunjukkan bahwa penerapan end plate pada ujung sayap menjadikan distribusi tekanan lebih merata di permukaan sayap sehingga terjadi peningkatan nilai gaya angkat.

Kata kunci: Winglet, Wing Tip Devices, Simulasi, Pesawat UAV, Cant Angle, Glider

\begin{abstract}
Air flow moving from high pressure to low pressure produces vortex at wing tip known as wing tip vortices. Wing tip vortices generate downwash flow and reduce distribution of pressure on the wing. Many types of wing tip devices had been designed to reduce wing tip vortices effect, one of the design is known as end plate wing tip devices. Research of wing tip devices with cant angle variation can be conducted by simulation approach. The end plate wing tip devices has been designed according to the upper section of with comb winglet. The object of simulation was a glider plane model without end plate, end plate with cant angel $0^{\circ}$ and $15^{\circ}$. Simulation had been observed with three variations of cruising speed: 50,60 , and $70 \mathrm{~km} / \mathrm{h}$. Simulation result shows the $15^{\circ}$ end plate can increase $4.1 \%$ lift at $70 \mathrm{~km} / \mathrm{h}$, and reduce $1.04 \%$ drag at $50 \mathrm{~km} / \mathrm{h}$ compared to wing tip without end plate. Contour and iso surface result the end plate make pressure distribution on wing pressure more uniform and generated more lift.
\end{abstract}

Keywords: Winglet, Wing Tip Vortices, Simulation, UAV, Cant Angle, Glider 


\section{Pendahuluan}

Gaya angkat atau lift pada sayap pesawat diperoleh dari hasil perbedaan tekanan pada bagian atas dan bawah permukaan sayap. Tekanan pada permukaan bawah sayap lebih tinggi daripada permukaan atas yang disebabkan oleh kecepatan aliran udara yang lebih lambat dibandingkan bagian atasnya. Aliran udara yang bergerak dari tekanan tinggi ke tekanan rendah menimbulkan aliran pusaran pada ujung sayap atau biasa dikenal sebagai wing tip vortices. Wing tip vortices menyebabkan kecenderungan udara untuk bergerak ke bawah yang secara tidak langsung mengubah sudut serang sayap sehingga lift berkurang. Selain itu, wing tip vortices menyebabkan distribusi tekanan pada sayap pesawat tidak merata serta menghasilkan gaya hambat atau drag yang menghambat laju pesawat [1].

Untuk meningkatkan performa aerodinamika, optimalisasi bentuk pesawat terus dikembangkan, salah satunya dengan menambahkan wing tip devices [2]. Penggunaan wing tip devices mampu meningkatkan gaya angkat atau lift terhadap gaya hambat atau drag hingga $7 \%$ [3]. Berbagai tipe wing tip devices kemudian dirancang sesuai dengan jenis pesawat, salah satunya adalah wing tip devices jenis end plate. End plate merupakan komponen berupa pelat tipis dengan ukuran dan sudut kemiringan tertentu yang diletakkan pada ujung sayap pesawat [4].

Bentuk end plate yang sederhana dan mudah untuk diproduksi menjadikan wing tip devices jenis ini sangat efektif untuk diaplikasikan pada pesawat model Unmanned Aerial Vehicle (UAV) jenis fixed wing glider. End plate yang diaplikasikan pada ujung sayap pesawat diharapkan dapat meningkatkan gaya angkat atau lift dan mengurangi gaya hambat atau drag pada pesawat [5].

Tujuan penelitian ini adalah untuk mengetahui pengaruh wing tip devices jenis end plate terhadap lift dan drag yang dihasilkan pesawat model UAV jenis fixed wing glider menggunakan pendekatan simulasi. Evolusi kemampuan komputer yang semakin baik menjadikan penggunaan metode simulasi menjadi semakin lebih baik dan akurat [6]. Simulasi dilakukan dengan variasi sudut kemiringan dan kecepatan terbang untuk mengetahui konfigurasi end plate yang tepat berdasarkan data yang diperoleh.

\section{Metode Penelitian}

Pesawat model UAV yang menjadi objek penelitian adalah Solfix UAV yang merupakan pesawat model UAV jenis fixed wing glider. Solfix UAV dibangun untuk keperluan observasi titik api kebakaran hutan seperti yang ditunjukan pada Gambar 2.1. Solfix UAV memiliki panjang sayap $1700 \mathrm{~mm}$ dengan panjang total pesawat $1450 \mathrm{~mm}$. Sayap Solfix UAV menggunakan airfoil jenis Eppler 668. Konfigurasi sayap dihedral dengan sudut $15^{\circ}$ pada jarak $600 \mathrm{~mm}$ dari badan pesawat atau fuselage. Kecepatan terbang pesawat $50-70 \mathrm{~km} / \mathrm{jam}$ dengan waktu jelajah maksimum 15 menit penerbangan. Solfix UAV menggunakan material kayu balsa yang diperkuat dengan serat karbon pada bagian sayap yang dilapisi material pembungkus jenis monokote [7].

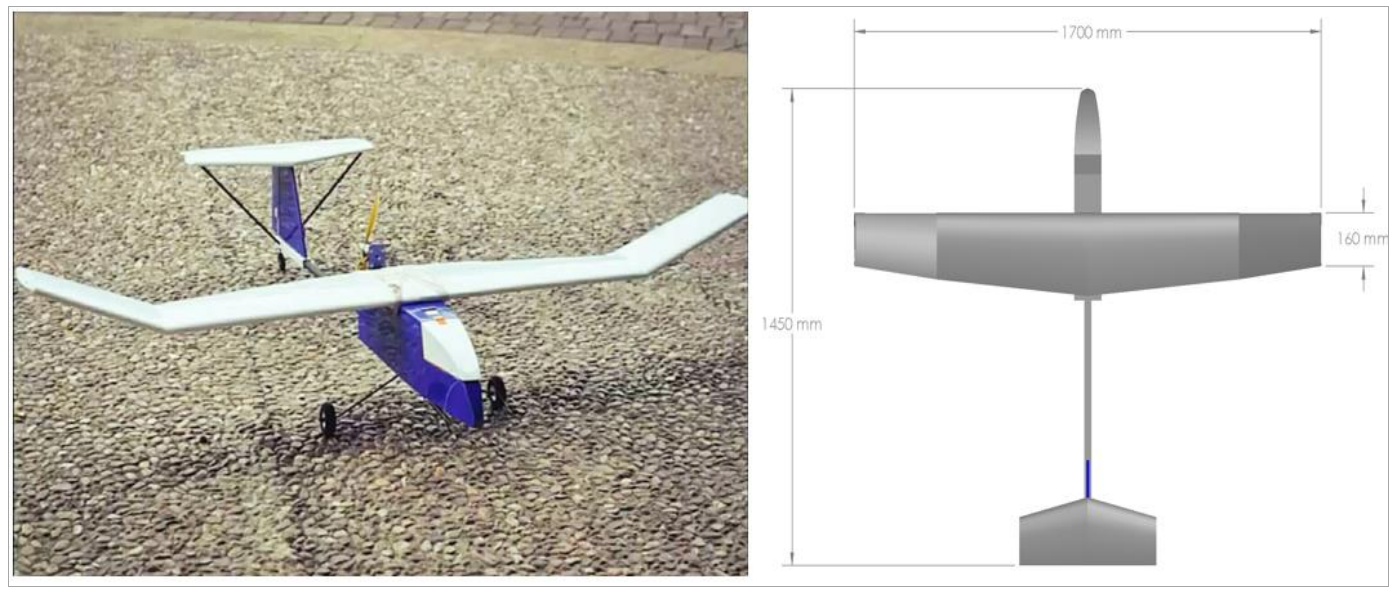

Gambar 2.1. Pesawat model Solfix UAV (Azmi A. Azhim, 2014) 
Wing tip devices tipe end plate diterapkan pada ujung sayap pesawat dengan geometri yang mengacu pada Withcomb winglet. Withcomb winglet merupakan geometri wing tip devices yang didesain oleh Richard T. Withcomb dan resmi dipublikasikan oleh NASA pada tahun 1976. Withcomb merupakan jenis wing tip devices yang umum digunakan dengan menggunakan parameter panjang cord sayap sebagai acuan dimensi seperti yang ditunjukan pada Gambar 2.2.

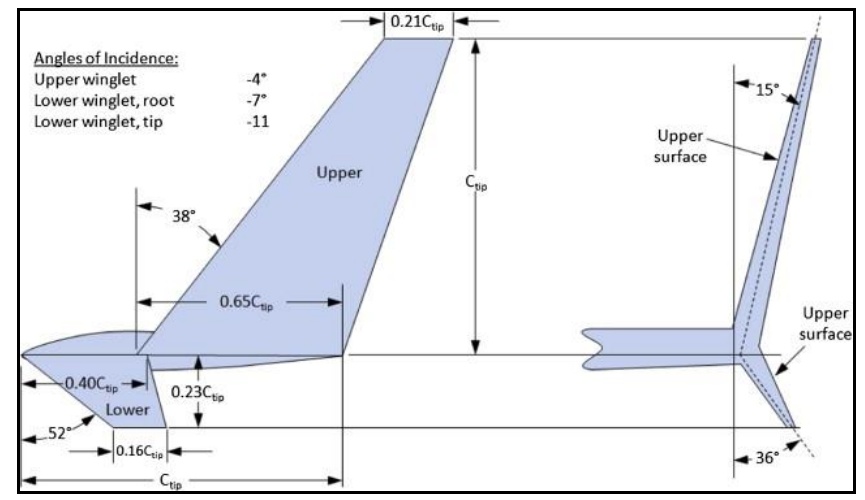

Gambar 2.2. Withcomb winglet (P. Panagiotou, 2014)

Pada penelitian ini geometri Withcomb winglet yang menjadi acuan hanya bagian atas. Dimensi geometri disesuaikan terhadap panjang cord sayap pesawat model Solfix UAV, yaitu $160 \mathrm{~mm}$ dan tebal end plate $2 \mathrm{~mm}$. Bentuk membulat atau fillet dengan radius $320 \mathrm{~mm}$ diterapkan pada bagian depan end plate. Adapun detail dari geometri end plate yang digunakan pada penelitian ini dapat dilihat pada Gambar 2.3.

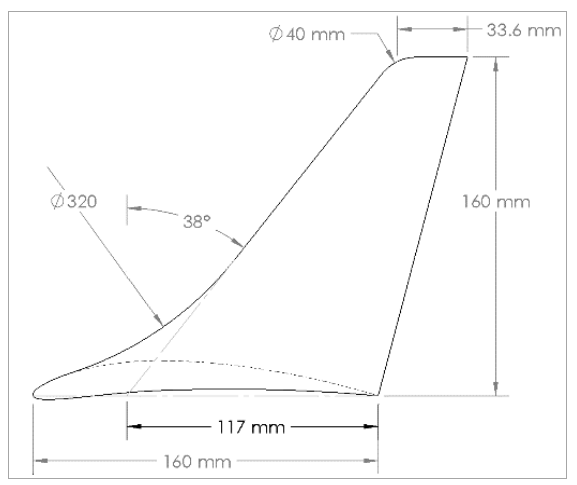

Gambar 2.3. Rancangan End Plate pada sayap pesawat model Solfix UAV

Simulasi yang digunakan pada penelitian ini menggunakan Ansys Fluent pada kondisi steady state. Geometri pesawat digambar dengan skala 1:1 dengan mengabaikan landing gear, motor penggerak serta propeller. Variasi geometri yang disimulasikan meliputi: simulasi pesawat model Solfix UAV tanpa end plate; end plate dengan sudut kemiringan $0^{\circ}$; dan end plate dengan sudut kemiringan $15^{\circ}$ seperti yang ditunjukkan Gambar 2.4.

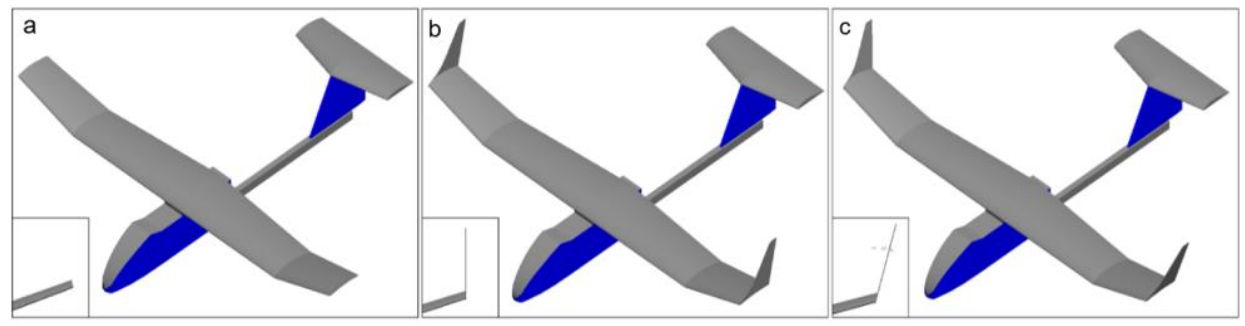

Gambar 2.4. (a) Tanpa End Plate; (b) End Plate 0 ; (c) End Plate $15^{\circ}$ 
Jenis mesh yang digunakan pada simulasi ini menggunakan tetrahedral mesh. Pembentukan mesh memiliki pengaruh besar terhadap hasil simulasi [8]. Proses refinement mesh dilakukan menggunakan metode body influence serta penerapan $y+$ atau inflation di seluruh geometri pesawat untuk mendapatkan hasil yang baik di daerah sekitar wall seperti yang ditunjukkan pada Gambar 2.5. Ukuran mesh di sekitar badan dan sayap pesawat menggunakan ukuran yang lebih kecil dibandingkan mesh lainnya. Hal ini dilakukan agar gradien tekanan dan kecepatan yang dihasilkan lebih baik [9]. Solver yang digunakan adalah RANS dengan model turbulen K-Epsilon. Solver RANS dapat memprediksi nilai drag dengan lebih baik [10] Parameter inlet menggunakan velocity inlet dengan nilai parameter sebesar 50; 60; dan $70 \mathrm{~km} / \mathrm{jam}$ pada tekanan $1 \mathrm{~atm}$.

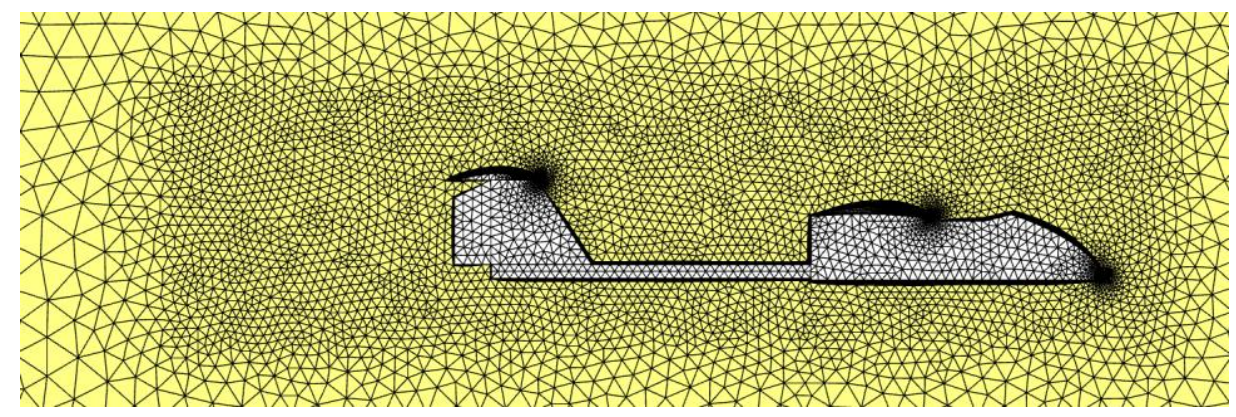

Gambar 2.5. Mesh dengan Body Influence Refinement

\section{Hasil dan Pembahasan}

Post processing dilakukan untuk memperoleh data hasil simulasi dan melakukan perbandingan variasi end plate pada pesawat model Solfix UAV. Hasil yang diperoleh dari post processing berupa kontur distribusi tekanan, kontur distribusi intensitas turbulen serta kontur vorticity yang dihasilkan oleh ujung sayap. Nilai lift dan drag selanjutnya menjadi salah satu parameter pembanding penggunaan end plate pada penelitian ini.

Hasil simulasi menunjukan bahwa distribusi tekanan pada sayap pesawat model Solfix UAV tanpa end plate tidak merata di sepanjang permukaan sayap. Tekanan yang dihasilkan pada ujung sayap lebih rendah daripada tekanan yang dihasilkan pada bagian tengah dan pangkal sayap akibat dari pusaran aliran yang terbentuk seperti yang ditunjukkan pada Gambar 3.1.

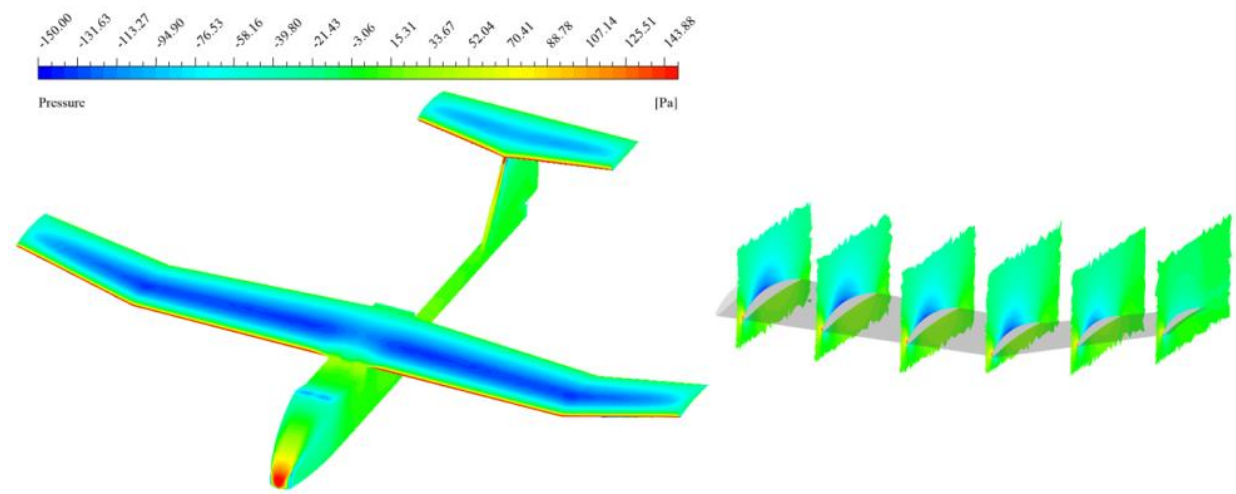

Gambar 3.1. Distribusi tekanan pada sayap pesawat model Solvix UAV tanpa End Plate

Pada Gambar 3.1 terlihat bahwa tekanan di daerah ujung sayap pada permukaan atas lebih tinggi daripada di bagian tengah maupun pangkal. Hal ini menunjukan bahwa perbedaan tekanan pada permukaan atas dan bawah di daerah ujung sayap tidak terlalu besar.

Distribusi tekanan pada ujung sayap yang lebih rata dihasilkan oleh sayap pesawat model Solfix UAV dengan penambahan end plate dengan sudut kemiringan $0^{\circ}$ seperti yang 
ditunjukkan pada Gambar 3.2. End plate yang ditempatkan pada ujung sayap mampu meminimalisir aliran pusaran yang terjadi sehingga perbedaan tekanan pada permukaan bawah dan atas sayap lebih besar dibandingkan tanpa end plate.

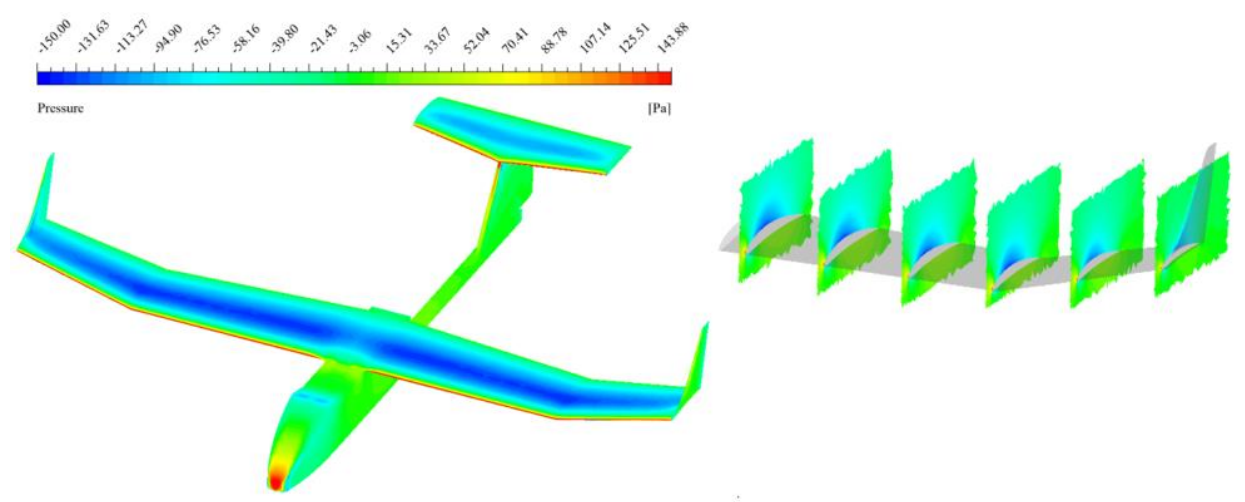

Gambar 3.2. Distribusi tekanan pada sayap pesawat model Solvix UAV menggunakan End Plate $0^{\circ}$

Peningkatan tekanan di daerah permukaan ujung sayap bagian bawah juga terjadi ketika menggunakan end plate dengan sudut kemiringan $15^{\circ}$ seperti yang ditunjukkan pada Gambar 3.3. Adapun peningkatan tekanan pada ujung sayap yang menggunakan end plate dengan sudut kemiringan $15^{\circ}$ tidak jauh berbeda dengan yang dihasilkan end plate sudut kemiringan $0^{\circ}$.

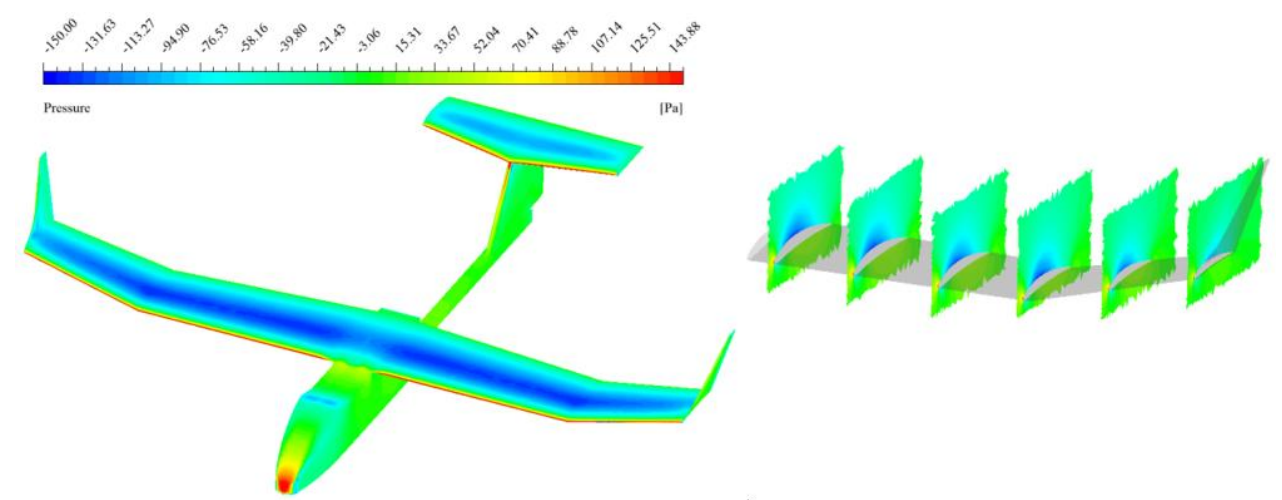

Gambar 3.3. Distribusi tekanan pada sayap pesawat model Solvix UAV menggunakan End Plate $15^{\circ}$

Distribusi tekanan yang yang tidak merata pada ujung sayap pesawat model Solfix diakibatkan oleh aliran pusaran atau wing tip vortices. Hasil iso surface dari simulasi menunjukan bahwa bahwa wing tip vortices pada ujung sayap pesawat model Solfix UAV tanpa end plate mempengaruhi permukaan atas sayap seperti yang ditunjukkan pada Gambar 3.4. 


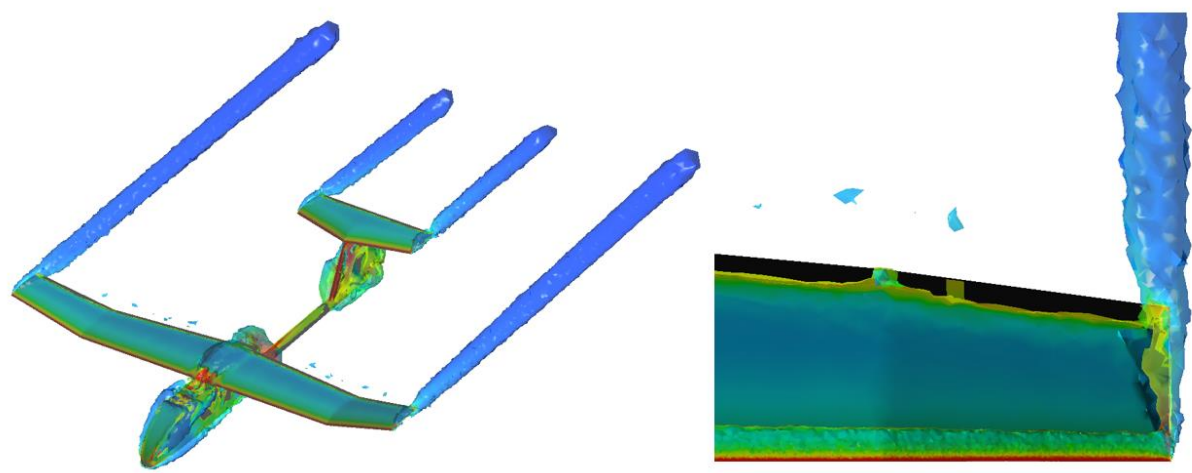

Gambar 3.4. Iso Surface Wing Tip Vortices pada ujung sayap pesawat model Solfix UAV tanpa End Plate

Wing tip vortices pada ujung sayap masih terbentuk ketika menggunakan end plate dengan sudut kemiringan $0^{\circ}$ dan $15^{\circ}$ seperti yang ditunjukkan pada Gambar 3.5. Perbedaan yang terlihat adalah bahwa pada end plate dengan sudut kemiringan $15^{\circ}$, wing tip vortices yang terjadi tidak mempengaruhi permukaan atas sayap secara signifikan. Hal ini disebabkan oleh pergerakan wing tip vortices yang terhalang oleh end plate.

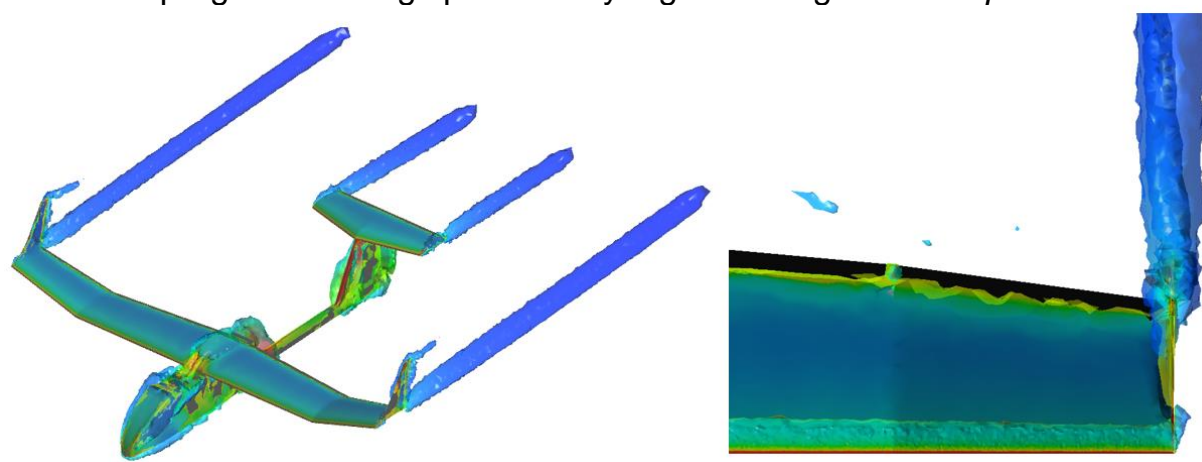

Gambar 3.5. Iso Surface Wing Tip Vortices pada ujung sayap pesawat model Solfix UAV menggunakan End Plate dengan sudut kemiringan $0^{\circ}$

Pada end plate dengan sudut kemiringan $15^{\circ}$, wing tip vortices yang dihasilkan pada ujung sayap terlihat serupa dengan end plate pada sudut kemiringan $0^{\circ}$. Wing tip vortices tidak mempengaruhi bagian permukaan atas sayap pesawat secara signifikan, akan tetapi intensitas yang dihasilkan sedikit lebih besar seperti yang ditunjukkan pada Gambar 3.6.

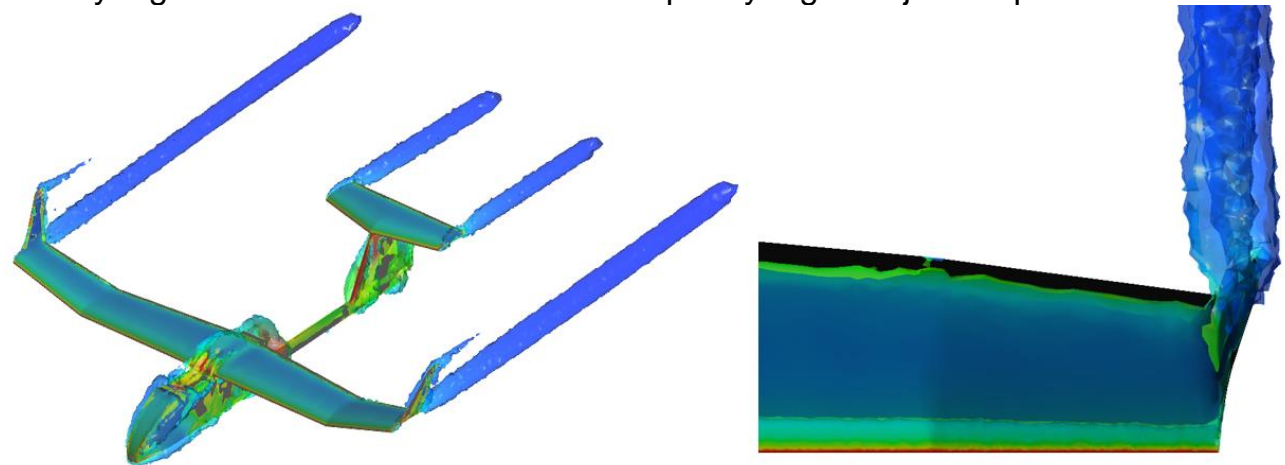

Gambar 3.6. Iso Surface Wing Tip Vortices pada ujung sayap pesawat model Solfix UAV menggunakan End Plate dengan sudut kemiringan $15^{\circ}$

Observasi lebih lanjut kemudian dilakukan dengan membuat kontur pada daerah sapuan atau wake ujung sayap. Kontur pada Gambar 3.7 memperlihatkan bahwa wing tip vortices yang dihasilkan tanpa end plate lebih besar dibandingkan dengan sayap yang 
menggunakan end plate. Intensitas terebentuknya wing tip vortices berkurang seiring bertambahnya jarak wake.

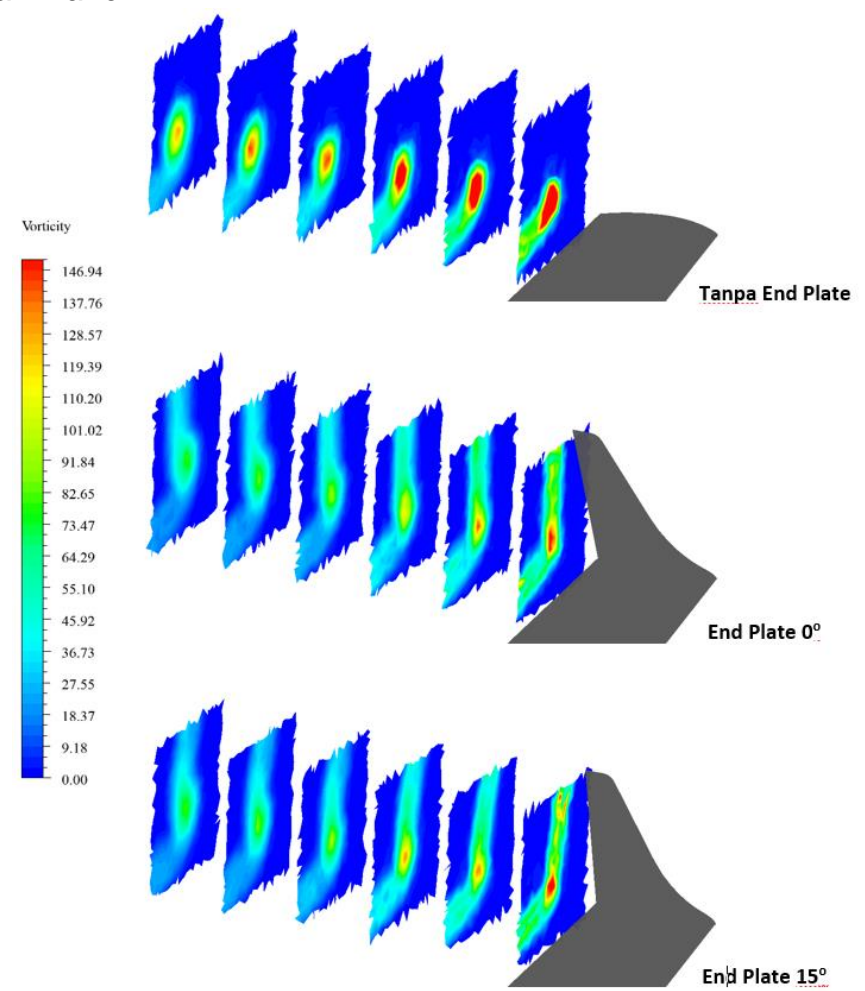

Gambar 3.7. Kontur Daerah Wake Wing Tip Vortices pada ujung sayap pesawat model Solfix tanpa End Plate dan menggunakan End Plate

Distirbusi tekanan yang tidak merata pada sayap yang diakibatkan oleh wing tip vortices mempengaruhi nilai lift yang dihasilkan. Hasil simulasi menunjukkan bahwa terjadi peningkatan nilai lift ketika menggunakan end plate pada ujung sayap seperti yang ditunjukkan pada Gambar 3.8.

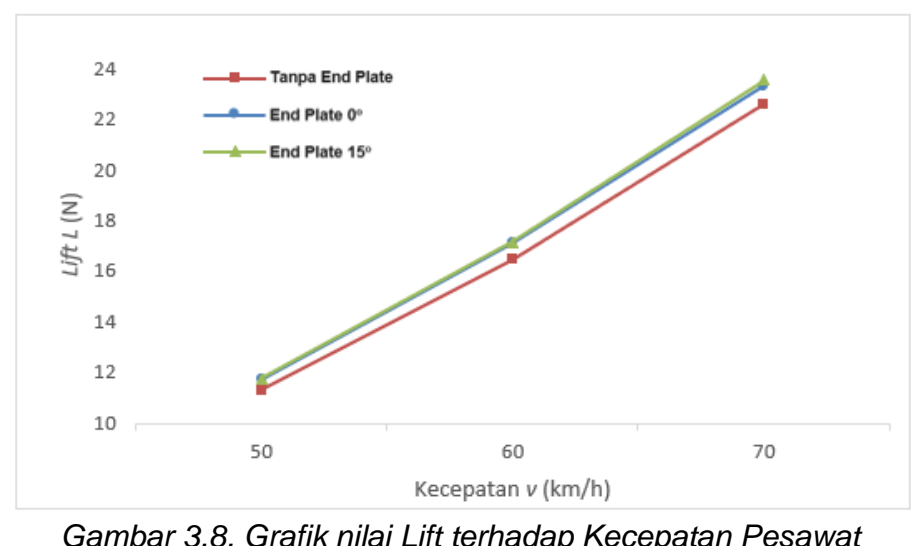

Pada Gambar 3.8 dapat diketahui bahwa penerapan end plate pada ujung sayap pesawat meningkatkan nilai lift untuk setiap variasi kecepatan. Pada kecepatan terbang 50 $\mathrm{km} / \mathrm{jam}$, sayap tanpa end plate menghasilkan nilai lift sebesar 11,326 N. Peningkatan nilai lift kemudian meningkat menjadi $11,749 \mathrm{~N}$ atau 3,7\% ketika menggunakan end plate dengan sudut kemiringan $0^{\circ}$. peningkatan nilai lift kemudian terjadi pada sayap dengan end plate sudut kemiringan $15^{\circ}$ menjadi $11,783 \mathrm{~N}$ atau sebesar $4 \%$. Sudut kemiringan pada end plate tidak memberikan peningkatan yang signifikan terhadap nilai lift pada kecepatan terbang 50 $\mathrm{km} / \mathrm{jam}$. 
Hasil yang sama ditunjukkan pada kecepatan terbang $60 \mathrm{~km} / \mathrm{jam}$, sudut kemiringan tidak berpengaruh terlalu banyak terhadap lift yang dihasilkan oleh pesawat. Lift yang dihasilkan pesawat model Solfix UAV tanpa end plate sebesar 16,501 N. Penerapan end plate dengan sudut kemiringan $0^{\circ}$ pada ujung sayap kemudian meningkatkan nilai lift menjadi $17,135 \mathrm{~N}$ atau sebesar $3,8 \%$, sedangakan end plate dengan sudut kemiringan $15^{\circ}$ meningkatkan nilai lift menjadi 17,166 $\mathrm{N}$ atau lebih besar 4\% dibandingkan dengan ujung sayap tanpa end plate.

Pada variasi kecepatan terbang $70 \mathrm{~km} / \mathrm{jam}$, lift yang dihasilkan sayap tanpa end plate sebesar 22,64 N. Penerapan end plate dengan sudut kemiringan $0^{\circ}$ meningkatkan lift menjadi $23,35 \mathrm{~N}$ atau sebesar $3,1 \%$, sedangkan end plate dengan sudut kemiringan $15^{\circ}$ pada ujung sayap meningkatkan nilai lift menjadi $23,57 \mathrm{~N}$ atau meningkat sebesar $4,1 \%$.

Hasil simulasi menunjukkan terjadinya peningkatan persentase nilai lift ketika ujung sayap pesawat menggunakan end plate. Penurunan persentase nilai lift terjadi pada end plate dengan sudut kemiringan $0^{\circ}$ ketika kecepatan terbang pesawat $70 \mathrm{~km} / \mathrm{jam}$. Penurunan nilai lift tidak terjadi pada end plate dengan sudut kemiringan $15^{\circ}$. hal ini menunjukkan bahwa sudut kemiringan pada end plate $15^{\circ}$ lebih tepat digunakan untuk pesawat model jenis glider dengan kecepatan terbang yang tinggi.

Nilai drag yang dihasilkan oleh keseluruhan bagian pesawat dipantau untuk mengetahui pengaruh penerapan end plate pada ujung sayap Solfix UAV. Hasil simulasi menunjukan bahwa terdapat penurunan nilai drag pada pesawat ketika menggunakan end plate walaupun tidak signifikan seperti yang ditunjukkan pada Gambar 3.9.

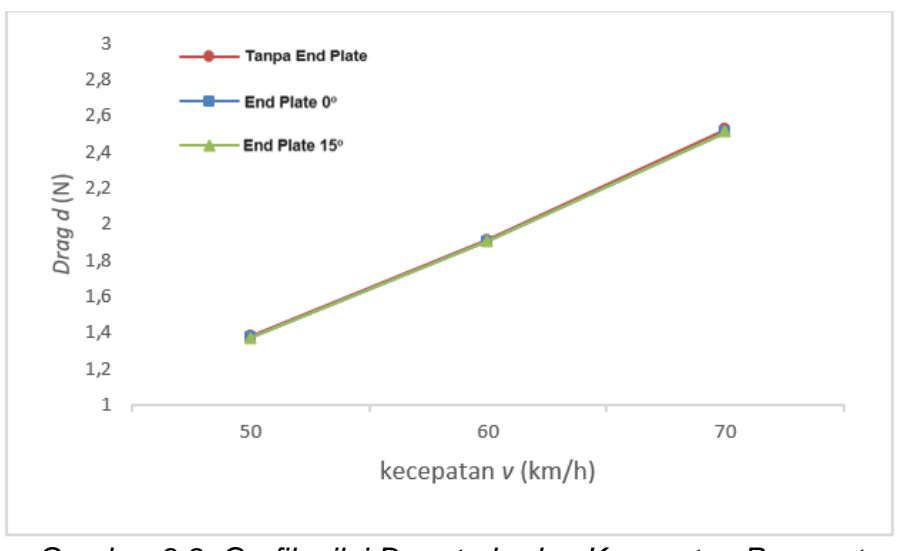

Gambar 3.9. Grafik nilai Drag terhadap Kecepatan Pesawat

Pada kecepatan terbang $50 \mathrm{~km} / \mathrm{jam}$, pesawat model Solfix UAV menghasilkan niai drag sebesar $1,38 \mathrm{~N}$. Hasil simulasi menunjukkan penurunan nilai drag menjadi $1,371 \mathrm{~N}$ atau $0,72 \%$ ketika menggunakan end plate dengan sudut kemiringan $0^{\circ}$. Pada end plate dengan sudut kemiringan $15^{\circ}$, nilai drag turun menjadi $1,367 \mathrm{~N}$ atau $1,02 \%$ dibandingkan tanpa end plate.

Pada kecepatan $60 \mathrm{~km} / \mathrm{jam}$, drag yang dihasilkan pesawat sebesar 1,91 N tanpa menggunakan end plate. Penurunan nilai drag yang seragam terjadi pada end plate $0^{\circ}$ dan $15^{\circ}$. Terjadi penurunan nilai $d r a g$ pada pesawat pada end plate dengan sudut kemiringan $0^{\circ}$ dan $15^{\circ}$ menjadi $1.90 \mathrm{~N}$ atau sebesar $0,42 \%$ dibandingkan ujung sayap tanpa end plate.

Drag dihasilkan oleh pesawat model Solfix UAV sebesar 2,52 N pada kecepatan terbang $70 \mathrm{~km} / \mathrm{jam}$. Nilai drag turun menjadi $2,51 \mathrm{~N}$ atau $0,63 \%$ ketika menggunakan end plate dengan sudut kemiringan $0^{\circ}$ dan $15^{\circ}$. Persentase penurunan drag yang tidak terlalu signifikan terjadi karena wing tip devices tipe end plate masih tetap menghasilkan wing tip vortices di daerah end plate yang menyebabkan induce drag walaupun intensitasnya menurun dibandingkan sayap tanpa end plate.

\section{KESIMPULAN}

Penerapan wing tip devices tipe end plate pada pesawat model jenis glider dapat meningkatkan nilai lift pada setiap variasi kecepatan 50, 60, dan $70 \mathrm{~km} / \mathrm{jam}$. Persentase 
peningkatan lift terbesar terjadi pada kecepatan $70 \mathrm{~km} / \mathrm{jam}$ dengan sudut kemiringan end plate $15^{\circ}$. penerapan end plate juga berpengaruh pada penurunan nilai drag pesawat walaupun tidak terlalu signifikan. Persentase penurunan drag terbesar terjadi pada kecepatan $70 \mathrm{~km} / \mathrm{jam}$ menggunakan end plate dengan sudut cant $0^{\circ}$ dan $15^{\circ}$. Dari pengamatan kontur, iso surface serta data lift dan drag yang dihasilkan dapat diketahui bahwa penerapan end plate pada ujung sayap lebih berpengaruh terhadap peningkatan lift yang menjadikan distribusi tekanan pada permukaan sayap yang lebih merata dibandingkan penurunan induce drag yang disebabkan oleh wing tip vortices.

\section{Daftar Pustaka}

[1] P. Panagiotou and K. Yakinthos, "Aerodynamic efficiency and performance enhancement of fixed-wing UAVs," Aerosp. Sci. Technol., vol. 99, p. 105575, 2020.

[2] S. G. Kontogiannis and J. A. Ekaterinaris, "Design, performance evaluation and optimization of a UAV," Aerosp. Sci. Technol., vol. 29, no. 1, pp. 339-350, 2013.

[3] J. Masud, Z. Toor, F. Akram, Z. Abbas, and U. Ahsun, "Part II: Winglet design and optimization for a low-speed subsonic UAV wing," in $55^{\text {th }}$ AIAA Aerospace Sciences Meeting, no. 210059, 2017.

[4] P. Panagiotou, P. Kaparos, and K. Yakinthos, "Winglet design and optimization for a MALE UAV using CFD," Aerosp. Sci. Technol., vol. 39, pp. 190-205, 2014.

[5] S. Rajendran, "Design of Parametric Winglets and Wing tip devices - A Conceptual Design Approach," PhD Thesis. Linkoping studies in Science and Technology, 2012.

[6] W. Yamazaki, K. Matsushima, and K. Nakahashi, "Aerodynamic design optimization using the drag-decomposition method," AIAA J., vol. 46, no. 5, pp. 1096-1106, 2008.

[7] Azmi A. Azhim, "Perancangan Sistem Unmanned Aerial Vehicle (UAV) Pada Pesawat Model Solfix." Yogyakarta: Program Studi Teknik Mesin Universitas Muhammadiyah Yogyakarta, 2014.

[8] S. P. Setyo Hariyadi, W. A. Widodo, M. A. Mustaghfirin, and A. Rachmadiyan, "Numerical study of flow characteristics on wing airfoil eppler 562 with whitcomb winglet variations," MATEC Web Conf., vol. 204, p. 04009, 2018.

[9] A. Rajesh, R. A, Badri, and M. S. G. Prasad, "Numerical analysis on the effect of fluidic on demand winglet on the aerodynamic performance of the wing," J. Aeronaut. Aerosp. Eng., vol. 6, no. 03, pp. 198-2013, 2017.

[10] A. Büscher, R. Radespiel, and T. Streit, "Modelling and design of wing tip devices at various flight conditions using a databased aerodynamic prediction tool," Aerosp. Sci. Technol., vol. 10, no. 8, pp. 668-678, 2006. 